\title{
IMPLEMENTASI MODEL ACCELERATED FAILURE TIME (AFT) BERDISTRIBUSI LOG-LOGISTIK PADA PASIEN PENYAKIT JANTUNG BAWAAN
}

\author{
Dwi Nooriqfina*, Sudarno ${ }^{2}$, Rukun Santoso ${ }^{3}$ \\ 1,2,3 Departemen Statistika, Fakultas Sains dan Matematika, Universitas Diponegoro \\ *e-mail (dwinooriqfina@ students.undip.ac.id)
}

\begin{abstract}
Log-Logistic Accelerated Failure Time (AFT) model is survival analysis that is used when the survival time follows Log-Logistic distribution. Log-Logistic AFT model can be used to estimate survival time, survival function, and hazard function. Log-Logistic AFT model was formed by regressing covariates linierly against the log of survival time. Regression coefficients are estimated using maximum likelihood method. This study uses data from Atrial Septal Defect (ASD) patients, which is a congenital disease with a hole in the wall that separates the top of two chambers of the heart by using sensor type III. Survival time as the response variable, that is the time from patient was diagnosed with ASD until the first relapse and uses age, gender, treatment status (catheterization/surgery), defect size that is the size of the hole in the heart terrace, pulmonary hypertension status, and pain status as predictor variables. The result showed that variable gender, treatment status, defect size, pulmonary hypertension status, and pain status affect the first recurrence of ASD patients, so it is found that category of female, untreated patient, defect size $\geq 12 \mathrm{~mm}$, having pulmonary hypertension, having chest pain tend to have first recurrence sooner than the other category.
\end{abstract}

Keywords: Atrial Septal Defect, Survival Analysis, Log-Logistic Accelerated Failure Time Model.

\section{PENDAhULUAN}

Atrial Septal Defect (ASD) atau defek septum atrium adalah kelainan akibat adanya lubang pada septum intersisial yang memisahkan antrium kiri dan kanan. Atrial Septal Defect (ASD) merupakan salah satu jenis dari penyakit jantung bawaan yang paling sering ditemukan adalah yaitu dengan insidensi $10 \%$ pada pasien dewasa dan $0,8 \%$ pada pasien bayi. ASD merupakan kelainan yang membutuhkan penangan yang harus dilakukan sejak dini dengan treatment kateterisasi ataupun pembedahan. Pada tahun 2019 RSUP Dr. Kariadi Semarang memiliki 274 pasien penderita ASD yang menjalani rawat jalan ataupun rawat inap. Pasien penderita ASD tersebut terdiri atas 11 pasien bayi, 91 pasien anak-anak dan 179 pasien usia, dengan rentang usia 1 hari hingga 69 tahun.

Analisis survival merupakan metode yang memanfaatkan data dengan informasi kronologis dari suatu kejadian atau peristiwa (event). Analisis survival memiliki perbedaan dengan analisis statistika lainnya yaitu pada konsep penyensoran. Penyensoran terjadi apabila kejadian memiliki informasi tentang waktu survival individu, tetapi tidak tahu secara pasti waktu survival-nya, maka data tersebut termasuk data tersensor (Kleinbaum \& Klein, 2005). Model Log-Logistik Accelerated Failure Time (AFT) merupakan salah metode yang dapat digunakan pada analisis survival jika data waktu survival diketahui mengikuti distribusi Log-Logistik. Metode parametrik tersebut dapat digunakan untuk mengetahui pengaruh suatu variable bebas terhadap waktu survival dan melihat nilai suatu variabel bebas dalam mempercepat terjadinya suatu peristiwa. Penelitian tugas akhir ini adalah menganalisis faktor-faktor yang mempengaruhi waktu kekambuhan pasien penderita Atrial Septal Defect (ASD) serta kondisi dari faktor-faktor tersebut dalam mempercepat terjadinya kekambuhan dengan menggunakan metode parametrik berdistribusi Log-Logistik Accelerated Failure Time (AFT). 


\section{TINJAUAN PUSTAKA}

\subsection{Analisis Survival}

Analisis survival merupakan metode yang digunakan untuk menggambarkan analisis data dalam bentuk waktu dimulai dari waktu asal terdefinisi sampai kejadian tertentu terjadi (Collet, 2004). Data waktu pada analisis survival digambarkan atau ditandai oleh tiga fungsi, yaitu fungsi ketahanan hidup, fungsi kepadatan peluang, dan fungsi kegagalan.

\subsubsection{Fungsi Padat Peluang}

Fungsi padat peluang dinotasikan dengan $f(t)$ dan didefinisikan sebagai probabilitas suatu individu gagal pada interval waktu $t$ sampai $t+\Delta t$ atau peluang kegagalan dalam interval per satuan waktu. Fungsi kepadatan peluang dinyatakan dengan

$$
f(t)=\lim _{\Delta t \rightarrow 0}\left[\frac{P(\text { objek gagal pada interval }(t+\Delta t)}{\Delta t}\right]
$$

$T$ merupakan variabel acak non-negatif dalam interval $[0, \infty)$ dan $F(t)$ merupakan fungsi distribusi kumulatif kontinu dari $T$. Fungsi ini didefinisikan sebagai peluang suatu individu mengalami kejadian sebelum waktu $t$ dan dituliskan dengan persamaan sebagai berikut:

$$
F(t)=P(T \leq t)
$$

\subsubsection{Fungsi Tahan Hidup}

Variabel random menyatakan waktu ketahanan hidup sebuah objek disimbolkan dengan $T$ dan fungsi ketahanan hidupnya dinotasikan dengan $S(t)$ yang menunjukan probabilitas suatu individu bertahan hidup lebih dari waktu $t$, dengan $t>0$. Maka $S(t)$ dapat didefinisikan sebagai berikut:

$$
\begin{aligned}
S(t) & =P(\text { individu bertahan lebih dari waktu } t) \\
& =P(T>t)) \\
& =1-P(\text { individu gagal sebelum waktu } t) \\
& =1-P(T \leq t) \\
S(t) & =1-F(t)
\end{aligned}
$$

\subsubsection{Fungsi Kegagalan}

Fungsi kegagalan didefinisikan sebagai tingkat kegagalan bersyarat yaitu probabilitas suatu individu gagal bertahan dalam interval waktu yang sangat pendek dari $t$ sampai $t+\Delta t$, jika diketahui bahwa individu tersebut telah bertahan hingga waktu $t$. Fungsi kegagalan dari waktu tahan hidup $T$ dinotasikan dengan $h(t)$ dan didefinisikan sebagai berikut:

$$
h(t)=\lim _{\Delta t \rightarrow 0}\left[\frac{P\left[\begin{array}{c}
\text { seorang individu gagal pada interval waktu }(t . t+\Delta t) \\
\text { jika diketahui indivudu tersebut telah brtahan hingga waktu } t
\end{array}\right]}{\Delta t}\right]
$$

Fungsi kegagalan juga dapat dinyatakan dengan menggunakan fungsi distribusi kumulatif $F(t)$ dan fungsi padat peluang $f(t)$, yaitu sebagai berikut:

$$
h(\mathrm{t})=\frac{f(\mathrm{t})}{1-F(\mathrm{t})}=\frac{f(\mathrm{t})}{S(\mathrm{t})}
$$

\subsubsection{Data Tersensor}

Penyensoran terjadi apabila kejadian memiliki informasi tentang waktu survival individu, tetapi tidak tahu secara pasti waktu survivalnya. Tiga tipe penyensoran yang sering digunakan dalam eksperimen uji hidup, yaitu sebagai berikut:

1. Sensor tipe I

Sensor tipe I adalah tipe penyensoran ketika semua $n$ objek masuk pada waktu yang sama dan percobaan akan dilakukan selama waktu $T$ yang telah ditentukan dan akan berakhir setelah 
mencapai waktu $T$, jika tidak ada objek yang hilang secara tiba-tiba maka waktu tahan hidup observasi tersensor sama dengan lama waktu pengamatan.

2. Sensor tipe II

Sensor tipe II adalah tipe penyensoran ketika semua objek yang diteliti $(n)$ masuk pada waktu yang bersamaan dan pengujian akan dihentikan sampai $r$ dari $n$ unit mengalami kematian.

3. Sensor tipe III

Sensor tipe III adalah tipe penyensoran ketika objek yang diteliti masuk ke dalam percobaan pada waktu yang berlainan selama periode waktu tertentu. Beberapa objek yang gagal atau mati sebelum pengamatan berakhir dapat diketahui waktu tahan hidupnya, beberapa objek yang lain keluar sebelum pengamatan berakhir dan sebagian lagi ada objek yang tetap hidup sampai batas waktu terakhir pengamatan.

\subsubsection{Distribusi Log-Logistik}

Distribusi Log-Logistik berasal dari distribusi Logistik dengan variabel random $Y$ yang mempunyai fungsi densitas peluang

$$
f(y)=\frac{s^{-1} \exp \left[\frac{(y-m)}{s}\right]}{\left\{1+\exp \left[\frac{(y-m)}{s}\right]\right\}^{2}},-¥<y<¥
$$

Variabel random $T$ dikatakan mengikuti distribusi Log-Logistik jika mempunyai fungsi densitas sebagai berikut:

$$
f(t)=\frac{e^{\theta} k t^{k-1}}{\left(1+e^{\theta} t^{k}\right)^{2}}
$$

Dengan $k=1 / \sigma, \theta=(-\mu / \sigma)$

Fungsi distribusi kumulatif $\quad: F(t)=\frac{e^{\theta} t^{k}}{1+e^{\theta} t^{k}}$

Fungsi tahan hidup $\quad: S(t)=\frac{1}{1+e^{\theta} t^{k}}$

Fungsi kegagalan

$$
: h(t)=\frac{e^{\theta} k t^{k-1}}{1+e^{\theta} t^{k}}
$$

\subsubsection{Estimasi Parameter}

1. Estimasi Parameter Secara Umum

Maximum Likelihood Estimation (MLE) merupakan metode yang digunakan untuk menaksir parameter yang tidak diketahui dari suatu populasi. Misalkan $X_{1}, X_{2}, \ldots, X_{n}$ adalah sampel random dari populasi dengan fungsi kepadatan peluang $f\left(x_{1}, x_{2}, \ldots, x_{n} \mid \beta\right)$ dan $\beta$ merupakan parameter yang dapat berbentuk tunggal namun juga dapat berbentuk vector yaitu $\boldsymbol{\beta}$ sehingga fungsi likelihoodnya sebagai berikut:

$$
L\left(\beta_{1}, \beta_{2}, \ldots, \beta_{P} \mid \mathbf{x}\right)=\prod_{i=1}^{n} f\left(x_{i} \mid \beta_{1}, \beta_{2}, \ldots, \beta_{P}\right)
$$

Untuk menentukan tasiran parameter dengan menggunakan MLE, terlebih dahulu mencari fungsi log likelihood dari persamaan (10), seperti yang tercantum pada persamaan berikut:

$$
l=\log L\left(\beta_{1}, \beta_{2}, \ldots, \beta_{P} \mid \mathbf{x}\right)=\log \left(\prod_{i=1}^{n} f\left(x_{i} \mid \beta_{1}, \beta_{2}, \ldots, \beta_{P}\right)\right)
$$

Bila fungsi likelihoodnya terdefinisikan dalam $\beta_{1}, \beta_{2}, \ldots, \beta_{p}$, maka calon estimator maksimum likelihood yang mungkin adalah $\hat{\beta}_{1}, \hat{\beta}_{2}, \ldots, \hat{\beta}_{p}$ sehingga 
$\frac{\partial}{\partial \beta_{j}} l\left(\beta_{1}, \beta_{2}, \ldots, \beta_{P} \mid \mathbf{x}\right)=0 \quad j=1,2, \ldots, p$

Untuk pembuktian bahwa $\hat{\beta}_{j}$ benar-benar memaksimumkan fungsi likelihood, dapat dibuktikan yaitu dengan menunjukan bahwa matrik Hessian bernilai definit negatif. Matrik Hessian adalah matrik simetri yang berisi persilangan turunan parsial dari $\frac{\partial^{2} l}{\partial \beta_{j} \beta_{s}}$ dengan $j=1,2, \ldots, p$ dan $s=1,2, \ldots, p$. Bentuk matrik Hessian adalah sebagai berikut:

$$
H=\left(\begin{array}{ccc}
\frac{\partial^{2} l}{\partial \beta_{1} \partial \beta_{1}} & \cdots & \frac{\partial^{2} l}{\partial \beta_{1} \partial \beta_{p}} \\
\vdots & \ddots & \vdots \\
\frac{\partial^{2} l}{\partial \beta_{p} \partial \beta_{1}} & \cdots & \frac{\partial^{2} l}{\partial \beta_{p} \partial \beta_{p}}
\end{array}\right)
$$

Matrik turunan kedua tersebut bernilai definit negatif jika $\mathbf{X}^{T} H \mathbf{X}<0, \forall \mathbf{X}$.

2. Estimasi parameter data tahan hidup tersensor tipe III

Apabila $f(t ; \theta)$ adalah fungsi probabilitas bersama dimana $t$ adalah realisasi dari $T$, maka fungsi likelihood dari $\theta$ dapat didefinisikan sebagai berikut:

$$
L(\theta \mid \boldsymbol{t})=f(t ; \theta)
$$

Untuk data survival yang diasumsikan independen dan identik serta lengkap, apabila ada $t_{1}, t_{2}, t_{3}, \ldots, t_{n}$ observasi, fungsi likelihood dapat ditulis :

$$
L(\theta \mid \boldsymbol{t})=\prod_{i=1}^{n} f\left(t_{i} ; \theta\right)
$$

Untuk data survival tidak lengkap dengan kemungkinan tersensor tipe III dapat direpresentasikan sebagai pasangan nilai observasi survival dengan status tersensornya yaitu $\left(t_{i}, \delta_{i}\right), i=1,2,3, \ldots, n$ dengan

$$
\delta_{i}=\left\{\begin{array}{l}
0 \text { jika i tersensor } \\
1 \text { jika i mendapat event }
\end{array}\right.
$$

Dengan asumsi masing-masing $\left(T_{i}, \delta_{i}\right)$ independent satu dengan yang lain, fungsi likelihood untuk data tersensor tipe III adalah :

$$
L(\theta \mid t)=\prod_{i=1}^{n} f\left(t_{i} \mid \theta\right)^{\delta_{i}} S\left(t_{i} \mid \theta\right)^{1-\delta_{i}}
$$

Dengan $\theta=\left(\theta_{1}, \theta_{2}, \ldots, \theta_{p}\right)$ adalah $p$ parameter yang akan destimasi, $f\left(t_{i} \mid \theta\right)$ adalah fungsi densitas untuk $i$ yang mendapatkan kejadian dan $S\left(t_{i} \mid \theta\right)$ adalah fungsi tahan hidup untuk $i$ yang tidak mendapat kejadian.

\subsection{Log-Logistik Accelerated Failure Time (AFT)}

\subsubsection{Model Log-Logistik AFT}

Model Accelerated Failure Time (AFT) memiliki asumsi bahwa efek kovariat multiplikatif terhadap waktu survival. Model AFT dapat dibentuk sebagai model linier dengan tranformasi log pada variabel random $T$ atau dapat dikatakan bahwa model AFT mengasumsikan hubungan antara log waktu survival $T$ linier dengan kovariat. Misal $T$ adalah waktu survival, $\mathbf{X}$ adalah vektor dari kovariat dan $\boldsymbol{\beta}^{\mathrm{T}}$ adalah vektor koefisien regresi, maka model AFT dapat ditulisan dalam persamaan sebagai berikut:

$$
\begin{aligned}
& Y=\ln T=\mu+\boldsymbol{\beta}^{\mathbf{T}} \mathbf{X}+\sigma W \\
& T=\exp \left(\mu+\boldsymbol{\beta}^{\mathbf{T}} \mathbf{X}+\sigma W\right)
\end{aligned}
$$


dengan $\mu$ adalah intersep, $\sigma$ adalah parameter skala, $W$ adalah error yang diasumsikan bersidtribusi logistik. Berdasarkan persamaan fungsi survival, maka model AFT (17) dapat dituliskan dalam persamaan sebagai berikut:

$$
S(t)=P(T>t)=P\left(\exp (\mu+\sigma W)>t \exp \left(-\boldsymbol{\beta}^{\mathrm{T}} \mathbf{X}\right)\right)
$$

Apabila semua $X$ bernilai 0 (baseline), maka $\boldsymbol{\beta}^{\mathrm{T}} \mathbf{X}$ akan bernilai 0 pula, dan $\exp \left(-\boldsymbol{\beta}^{\mathbf{T}} \mathbf{X}\right)=1$, asehingga fungsi baseline untuk model AFT sebagai berikut:

$$
S_{0}(t)=P(\exp (\mu+\sigma W)>t)
$$

Sehingga hubungan antara persamaan (19) dan (20) yaitu sebagai berikut:

$$
S(t)=S_{0}\left(t \exp \left(-\boldsymbol{\beta}^{\mathbf{T}} \mathbf{X}\right)\right)=S_{0}\left(\exp \left(-\boldsymbol{\beta}^{\mathbf{T}} \mathbf{X}\right) t\right)
$$

diperoleh fungsi kegagalan model AFT sebagai berikut:

$$
h(t)=\exp \left(-\boldsymbol{\beta}^{\mathbf{T}} \mathbf{X}\right) h_{0}\left(\exp \left(-\boldsymbol{\beta}^{\mathbf{T}} \mathbf{X}\right) t\right)
$$

1. Model Log-Logistik AFT tanpa efek kovariat

Misal variabel random waktu survival $T$ berdistribusi Log-Logistik dengan parameter $(\theta, k)$. Berikut akan dibahas terlebih dahulu model Log-Logistik AFT tanpa efek kovariat sehingga persamaan (17) menjadi $Y=\ln T=\mu+\sigma W$ dengan transformasi $\log$ waktu survival $Y=\ln T$, maka bentuk persamaan fungsi survival sebagai berikut:

$$
S_{Y}(y)=\frac{1}{1+e^{\theta+y k}}
$$

dengan $W$ adalah error yang memiliki bentuk fungsi survival sebagai berikut:

$$
\begin{aligned}
& S_{W}(w)=P(W>w)=P(Y>\mu+\sigma w)=S_{Y}(\mu+\sigma w)=\frac{1}{1+\exp (\theta+(\mu+\sigma w) k)} \\
& S_{W}(w)=\frac{1}{1+\exp (w)}
\end{aligned}
$$

Maka bentuk fungsi densitas untuk $W$ adalah sebagai berikut:

$$
f_{W}(w)=\frac{\exp (w)}{(1+\exp (w))^{2}}
$$

2. Model Log-Logistik AFT dengan efek kovariat:

Fungsi survival untuk $Y$ sebagai berikut:

$$
S_{Y}(y)=P(Y>y)=P\left(W>\frac{y-\mu-\boldsymbol{\beta}^{\mathrm{T}} \mathbf{X}}{\sigma}\right)=S_{W}\left(\frac{y-\mu-\boldsymbol{\beta}^{\mathrm{T}} \mathbf{X}}{\sigma}\right)
$$

Berdasarkan persamaan (24) maka diperoleh:

$$
S_{Y}(y)=\frac{1}{1+\exp \left(\frac{y-\mu-\boldsymbol{\beta}^{\mathrm{T}} \mathbf{X}}{\sigma}\right)}
$$

Fungsi densitas $Y$ sebagai berikut:

$$
f_{Y}(y)=-\frac{d}{d y} S_{Y}(y)=\frac{\exp \left(\frac{y-\mu-\boldsymbol{\beta}^{\mathrm{T}} \mathbf{X}}{\sigma}\right)}{\sigma\left(1+\exp \left(\frac{y-\mu-\boldsymbol{\beta}^{\mathrm{T}} \mathbf{X}}{\sigma}\right)\right)^{2}}
$$


Berdasarkan persamaan (21) dan (22) diperoleh fungsi survival dan fungsi kegagalan untuk model Log-Logistik AFT untuk waktu survival $T$ yaitu:

Fungsi survival model Log-Logistik AFT:

$$
S(t)=S_{0}\left(\exp \left(-\boldsymbol{\beta}^{\mathbf{T}} \mathbf{X}\right) t\right)=\frac{1}{1+e^{\theta^{+k\left(-\boldsymbol{\beta}^{\mathbf{T}} \mathbf{X}\right)}} t^{k}}
$$

Fungsi kegagalan model Log-Logistik AFT:

$$
h(t)=\exp \left(-\boldsymbol{\beta}^{\mathbf{T}} \mathbf{X}\right) h_{0}\left(\exp \left(-\boldsymbol{\beta}^{\mathbf{T}} \mathbf{X}\right) t\right)=\frac{e^{\theta+k\left(-\boldsymbol{\beta}^{\mathbf{T}} \mathbf{X}\right)} k t^{k-1}}{1+e^{\theta+k\left(-\boldsymbol{\beta}^{\mathbf{T}} \mathbf{x}\right)} t^{k}}
$$

\subsubsection{Estimasi Parameter pada Distribusi Log-Logistik Tersensor Tipe III}

Untuk mengestimasi parameter pada model Log-Logistik AFT dengan menggunakan metode maksimum likelihood, perhatikan model $\log$ linier waktu $Y=\ln T=\mu+\boldsymbol{\beta}^{\mathrm{T}} \mathbf{X}+\sigma W$ Berdasarkan persamaan (26) dan (27) maka fungsi likelihoodnya adalah:

$$
\begin{aligned}
L & =\prod_{i=1}^{n}\left[f_{Y}\left(y_{i}\right)\right]^{\delta_{i}}\left[S_{Y}\left(y_{i}\right)\right]^{1-\delta_{i}} \\
& =\prod_{i=1}^{n}\left(\frac{\exp \left(\frac{y-\mu-\boldsymbol{\beta}^{\mathrm{T}} \mathbf{X}}{\sigma}\right)}{\sigma\left(1+\exp \left(\frac{y-\mu-\boldsymbol{\beta}^{\mathrm{T}} \mathbf{X}}{\sigma}\right)\right)^{2}}\right)^{\delta_{i}}\left(\frac{1}{1+\exp \left(\frac{y-\mu-\boldsymbol{\beta}^{\mathrm{T}} \mathbf{X}}{\sigma}\right)}\right)^{1-\delta_{i}}
\end{aligned}
$$

Bentuk logaritma natural dari fungsi likelihood tersebut adalah:

$$
\begin{aligned}
& \left.l=\ln L=\ln \left(\prod_{i=1}^{n}\left(\frac{\exp \left(\frac{y-\mu-\boldsymbol{\beta}^{\mathbf{T}} \mathbf{X}}{\sigma}\right)}{\sigma\left(1+\exp \left(\frac{y-\mu-\boldsymbol{\beta}^{\mathbf{T}} \mathbf{X}}{\sigma}\right)\right)^{2}}\right)^{\delta_{i}}\left(\frac{1}{1+\exp \left(\frac{y-\mu-\boldsymbol{\beta}^{\mathbf{T}} \mathbf{X}}{\sigma}\right)}\right)\right)^{1-\delta_{i}}\right) \\
& l=\sum_{i=1}^{n}\left(\delta_{i} \ln \left(\frac{\exp \left(\frac{y-\mu-\boldsymbol{\beta}^{\mathbf{T}} \mathbf{X}}{\sigma}\right)}{\sigma\left(1+\exp \left(\frac{y-\mu-\boldsymbol{\beta}^{\mathbf{T}} \mathbf{X}}{\sigma}\right)\right)^{2}}\right)+\left(1-\delta_{i}\right) \ln \left(\frac{1}{1+\exp \left(\frac{y-\mu-\boldsymbol{\beta}^{\mathbf{T}} \mathbf{X}}{\sigma}\right)}\right)\right)
\end{aligned}
$$

Estimasi parameter $\mu$ dengan menggunakan persaman (30) diperoleh dengan cara menyelesaikan persamanaan:

$$
\frac{\partial l}{\partial \mu}=0
$$

Estimasi parameter $\sigma$ dengan menggunakan persaman (30) diperoleh dengan cara menyelesaikan persamanaan: $\quad \frac{\partial l}{\partial \sigma}=0$

Estimasi parameter $\beta_{j}$ untuk $j=1,2, \ldots, p$ dengan menggunakan persaman (30) diperoleh dengan cara menyelesaikan persamanaan: $\quad \frac{\partial l}{\partial \beta_{j}}=0$

Berdasarkan fungsi log likelihood terlihat bahwa estimasi parameter $\mu, \sigma$, dan $\beta_{j}$ tidak dapat diselesaikan secara eksak, sehingga diperlukan penyelesaiaan secara numerik 
menggunakan metode Newton-Raphson dengan bantuan software yang diselesaikan secara komputasi.

Berikut ini akan dijelaskan prosedur Newton-Raphson untuk menaksir parameter pada model Log-Logistik AFT dengan data tersensor tipe III. Misal matriks â adalah matriks kolom ukuran $p+2$ yang berisi taksiran parameter $\mu, \sigma, \beta_{1}, \ldots, \beta_{p}$ maka diperoleh bentuk matriks â sebagai berikut:

$$
\hat{\mathbf{a}}=\left[\begin{array}{c}
\hat{\mu} \\
\hat{\sigma} \\
\hat{\beta}_{1} \\
\vdots \\
\hat{\beta}_{p}
\end{array}\right]
$$

Matriks $\boldsymbol{G}\left(\mu, \sigma, \beta_{1}, \ldots, \beta_{p}\right)$ adalah matriks kolom ukuran $p+2$ yang berisikan turunan pertama fungsi log-likelihood terhadap parameter $\mu, \sigma, \beta_{1}, \ldots, \beta_{p}$. Maka matriks $\boldsymbol{G}\left(\mu, \sigma, \beta_{1}, \ldots, \beta_{p}\right)=0$ bersesuaian dengan persamaan (31) sampai (33). Jika $\hat{\mu}, \hat{\sigma}, \hat{\beta}_{1}, \ldots, \hat{\beta}_{p}$ adalah taksiran parameter $\mu, \sigma, \beta_{1}, \ldots, \beta_{p}$ yang memaksimumkan fungsi likelihood, maka matriks $\boldsymbol{G}\left(\hat{\mu}, \hat{\sigma}, \hat{\beta}_{1}, \ldots, \hat{\beta}_{p}\right)=0$ adalah:

$$
\boldsymbol{G}\left(\hat{\mu}, \hat{\sigma}, \hat{\beta}_{1}, \ldots, \hat{\beta}_{p}\right)=\left[\begin{array}{c}
\boldsymbol{G}_{1}\left(\hat{\mu}, \hat{\sigma}, \hat{\beta}_{1}, \ldots, \hat{\beta}_{p}\right) \\
\boldsymbol{G}_{2}\left(\hat{\mu}, \hat{\sigma}, \hat{\beta}_{1}, \ldots, \hat{\beta}_{p}\right) \\
\boldsymbol{G}_{3}\left(\hat{\mu}, \hat{\sigma}, \hat{\beta}_{1}, \ldots, \hat{\beta}_{p}\right) \\
\vdots \\
\boldsymbol{G}_{p+2}\left(\hat{\mu}, \hat{\sigma}, \hat{\beta}_{1}, \ldots, \hat{\beta}_{p}\right)
\end{array}\right]=\left[\begin{array}{c}
\frac{\partial l\left(\hat{\mu}, \hat{\sigma}, \hat{\beta}_{1}, \ldots, \hat{\beta}_{p}\right)}{\partial \hat{\mu}} \\
\frac{\partial l\left(\hat{\mu}, \hat{\sigma}, \hat{\beta}_{1}, \ldots, \hat{\beta}_{p}\right)}{\partial \hat{\sigma}} \\
\frac{\left.\partial \hat{\sigma}_{1}, \hat{\beta}_{1}, \ldots, \hat{\beta}_{p}\right)}{\partial \hat{\beta}_{1}} \\
\vdots \\
\frac{\partial l\left(\hat{\mu}, \hat{\sigma}_{1}, \ldots, \hat{\beta}_{p}\right)}{\partial \hat{\beta}_{p}}
\end{array}\right]=\left[\begin{array}{c}
0 \\
0 \\
0 \\
\vdots \\
0
\end{array}\right]
$$

Matriks $\boldsymbol{H}\left(\hat{\mu}, \hat{\sigma}, \hat{\beta}_{1}, \ldots, \hat{\beta}_{p}\right)$ merupakan matriks berukuran $([p+2] \times[p+2])$ yang berisikan turunan fungsi pada matriks $\boldsymbol{G}\left(\hat{\mu}, \hat{\sigma}, \hat{\beta}_{1}, \ldots, \hat{\beta}_{p}\right)$ terhadap $\hat{\mu}, \hat{\sigma}, \hat{\beta}_{1}, \ldots, \hat{\beta}_{p}$, maka matriks $\boldsymbol{H}\left(\hat{\mu}, \hat{\sigma}, \hat{\beta}_{1}, \ldots, \hat{\beta}_{p}\right)$ adalah:

$$
\boldsymbol{H}\left(\hat{\mu}, \hat{\sigma}, \hat{\beta}_{1}, \ldots, \hat{\beta}_{p}\right)=\left[\begin{array}{ccc}
\frac{\partial G_{1}}{\partial \hat{\mu}} & \cdots & \frac{\partial G_{1}}{\partial \hat{\beta}_{p}} \\
\vdots & \ddots & \vdots \\
\frac{\partial G_{p+2}}{\partial \hat{\mu}} & \cdots & \frac{\partial G_{p+2}}{\partial \hat{\beta}_{p}}
\end{array}\right]
$$


Prosedur Newton-Raphson untuk mencari taksiran â sehingga $\boldsymbol{G}\left(\hat{\mu}, \hat{\sigma}, \hat{\beta}_{1}, \ldots, \hat{\beta}_{p}\right)=0$ adalah sebagai berikut:

1. Input:

- $\quad$ Batas toleransi (tol)

- Taksiran awal $\left(\hat{\mathbf{a}}^{(0)}\right)$

2. Pada setiap iterasi ke- $r$

- Hitung taksiran baru untuk $\hat{\mathbf{a}}^{(r)}$ :

$\hat{\mathbf{a}}^{(r)}=\hat{\mathbf{a}}^{(r-1)}-\left[\boldsymbol{H}^{(r-1)}\left(\hat{\mu}, \hat{\sigma}, \hat{\beta}_{1}, \ldots, \hat{\beta}_{p}\right)\right]^{-1} \boldsymbol{G}^{(r-1)}\left(\hat{\mu}, \hat{\sigma}, \hat{\beta}_{1}, \ldots, \hat{\beta}_{p}\right)$

- Hitung error taksiran:

error $^{(r)}=\hat{\mathbf{a}}^{(r)}-\hat{\mathbf{a}}^{(r-1)}$

- Periksa kondisi berikut:

$\mid$ error $^{(r)} \mid>$ tol, lanjut ke iterasi berikutnya

$\mid$ error $^{(r)} \mid \leq$ tol, iterasi selesai

3. Output

- Taksiran untuk âadalah $\hat{\mathbf{a}}^{(r)}$

- Error dari taksiran yang diperoleh adalah $\mid$ error $^{(r)} \mid$

- Iterasi yang dilakukan adalah sebanyak $r$

Dengan metode Newton-Raphson maka taksiran untuk â pada persamaan (34) adalah $\hat{\mathbf{a}}^{(r)}$

\subsubsection{Uji Kecocokan Distribusi Log-Logistik}

Hipotesis :

$H_{0}$ : Data sampel hasil observasi dianggap berasal dari populasi yang berdistribusi Log-Logistik

$H_{1}$ : Data sampel hasil observasi dianggap berasal dari populasi yang tidak berdistribusi Log-Logistik

Tingkat signifikansi : $\alpha=5 \%$

Statistik Uji:

$A_{n, p}^{2}=-n-\frac{1}{n} \sum_{i=1}^{n}(2 i-1)\left[\ln F\left(t_{i}\right)+\ln \left(1-F\left(t_{n+1-i}\right)\right)\right] \quad$ dengan $p=\frac{r}{n}$

Kriteria Penolakan: $H_{0}$ ditolak jika nilai $A_{n, p}^{2}>D_{n, p}^{1-\alpha}$

\subsubsection{Ujian Signifikansi Parameter}

1. Pengujian Secara Serentak

Hipotesis

$H_{0}: \beta_{1}=\beta_{2}=\cdots=\beta_{P}=0$ (secara bersam-sama variabel independent tidak berpengaruh terhadap variabel dependen)

$H_{1}$ : minimal ada satu $\beta_{j} \neq 0$, dengan $j=1,2, \ldots, p$ (minimal ada satu vaiabel independent yang berpengaruh secara simultan terhadap variabel dependen)

Taraf Signifikansi: $\alpha=5 \%$

Statistik Uji: $G=-2[\ln (0)-\ln L(\hat{\beta})]$

dengan:

$\ln L(0)$ :log partial likelihood dari model tanpa variabel independen

$\ln L(\hat{\beta}): \log$ partial likelihood dari model yang terdiri dari $\mathrm{p}$ variabel independen 
Kriteria Penolakan: $H_{0}$ ditolak jika $G>c_{(\alpha, d b=p)}^{2}$ atau p-value $<\alpha$ dengan p adalah banyaknya parameter $\beta$

2. Pengujian Secara Parsial

Hipotesis

$H_{0}: \beta_{j}=0$, dengan $j=1,2, \ldots, p$ (variabel independent $\mathrm{j}$ tidak berpengaruh terhadap variabel dependen)

$H_{1}: \beta_{j} \neq 0$, dengan $j=1,2, \ldots, p$ (vaiabel independent $\mathrm{j}$ berpengaruh terhadap variabel dependen)

Taraf Signifikansi: $\alpha=5 \%$

Statistik Uji: $Z=\frac{\hat{\beta}_{j}}{S E \hat{\beta}_{j}}$ dengan $S E \hat{\beta}_{j}=\sqrt{\operatorname{var} \hat{\beta}_{j}}$

Kriteria Penolakan: $H_{0}$ ditolak jika $|Z|>Z_{\alpha / 2}$ atau p-value $<\alpha$

\section{METODE PENELITIAN}

\subsection{Jenis dan Sumber Data}

Jenis data yang digunakan merupakan data sekunder yang diperoleh dari dokumen rekam medis pasien penderita penyakit jantung bawaan jenis Atrial Septal Defect yang menjalani rawat inap atau rawat jalan di RSUP Dr. Kariadi Kota Semarang periode Januari 2019 sampai Desember 2019 yang berjumlah 113 data. Pengambilan data dilakukan di bagian rekam medis selama 1 bulan dengan cara pencatatan ulang variabel - variabel yang diperlukan untuk data masing -masing pasien.

\subsection{Variabel Penelitian}

Variabel yang digunakan terdiri atas lama waktu tahan hidup (survival), status sensor, usia, jenis kelamin, status treatment, ukuran defect, status hipertensi pulmonal, dan status nyeri. Variabel yang menyatakan penyensoran adalah variabel status sensor dengan penyensoran tipe III. Penyensoan berdasarkan data waktu tiap individu mulai diberi penanganan yang masing-masingnya dimulai dari waktu yang berbeda-beda hingga pasien mengalami kekambuahan pertama atau sampai akhir penelitian yaitu Desember 2019.

\subsection{Analisis Data}

Analisis data pada penelitian ini menggunakan software RStudio 3.6.0, Minitab 17 dan Microsoft Excel 2016. Langkah-langkah analisis yang dilakukan dalam penelitian ini adalah sebagai berikut:

1. Melakukan input data

2. Melakukan analisis deskriptif

3. Melakukkan uji kecocokan distribusi Log-Logistik untuk data waktu tahan hidup

4. Melakukan estimasi parameter menggunakan MLE

5. Melakukan uji signifikansi parameter

6. Membentuk model AFT

7. Melakukan interpretasi model AFT yang telah terbentuk

\section{HASIL DAN PEMBAHASAN}

Pada penelitian ini, event didefinisikan sebagai kekambuhan pertama pasien penderita ASD, sehingga untuk definisi fungsi survival, fungsi kepadatan peluang, fungsi kumulatif dan fungsi hazard didefinisikan sebagai berikut:

1. $S(t)$ : Probabilitas pasien penderita ASD tidak mengalami kekambuhan pertama lebih dari waktu $t$. 
2. $f(t)$ : Probabilitas pasien mengalami kekambuhan pertama dalam interval waktu $t$ sampai $t+\Delta t$.

3. $F(t)$ : Probabilitas pasien mengalami kekambuhan pertama sebelum waktu $t$.

4. $h(t)$ : Rate kegagalan pasien mengalami kekambuhan pertama dalam interval waktu $t$ sampai $t+\Delta t$, jika diketahui pasien tersebut tidak mengalami kekambuhan pertama hingga waktu $t$.

\subsection{Uji Distribusi Waktu Survival}

Berdasarkan hasil perhitungan menggunakan software Minitab 17 diperoleh nilai $A_{\text {hitung }}^{2}$ (Anderson-Darling) pada distribusi Log-Logistik sebesar 0,395 dengan nilai $D_{113 ; 0,9}^{0.95}=1,3581$ (berdasarkan Tabel Koziol and Byar). Sehingga pada taraf signifikansi 5\%, $H_{0}$ ditolak karena $A_{\text {hitung }}^{2}<D_{106 ; 0,9}^{0.95}$. Dapat disimpulkan bahwa waktu survival pasien penderita ASD berdistribusi Log-Logistik.

\subsection{Analisis Survival dengan Model Regresi AFT Log-Logistik}

\subsubsection{Regresi AFT Log-Logistik Model Awal}

Tabel 1. Hasil Estimasi Koefisien Regresi AFT Log-Logistik Model Awal

\begin{tabular}{lc}
\hline \multicolumn{1}{c}{ Variabel } & Estimasi Koefisien \\
\hline Intercept $(\mu)$ & 4.52962 \\
$X_{1}$ (Usia) & -0.00347 \\
$X_{2}$ (Laki-laki) & 0.53800 \\
$X_{3}$ (Kateterisasi/Operasi) & 0.71326 \\
$X_{4}(\geq 12 \mathrm{~mm})$ & -0.76395 \\
$X_{5}$ (Ada Hipertensi Pulmonal) & -0.33645 \\
$X_{6}($ Ya Nyeri) & -0.87516 \\
Scale $(\sigma)$ & 0.517 \\
\hline
\end{tabular}

$$
\theta=\frac{-\mu}{\sigma}=-8,7613 k=\frac{1}{\sigma}=1,9342
$$

Berdasarkan pada Tabel 2 dengan rumus (18), (28) dan (29) maka diperoleh:

-Estimasi waktu survival model awal sebagai berikut:

$$
\begin{aligned}
\hat{T}= & \exp \left(4,52962-0,00347 X_{1}+0,538 X_{2}+0,71326 X_{3}\right. \\
& \left.-0,76395 X_{4}-0,33645 X_{5}-0,87516 X_{6}\right)
\end{aligned}
$$

-Estimasi fungsi survival model awal sebagai berikut:

$$
\begin{aligned}
\hat{S}(t \mid X)= & {\left[1+\exp \left(-8,7613+1,9324\left(0,00347 X_{1}-0,538 X_{2}-0,71326 X_{3}\right.\right.\right.} \\
& \left.\left.\left.+0,76395 X_{4}+0,33645 X_{5}+0,87516 X_{6}\right)\right) t^{1,9324}\right]^{-1}
\end{aligned}
$$

-Estimasi fungsi kegagalan model awal sebagai berikut:

$$
\hat{h}(t \mid X)=\frac{\exp \left(\begin{array}{l}
-8,7613+1,9324\left(0,00347 X_{1}-0,538 X_{2}-0,71326 X_{3}\right. \\
+0,76395 X_{4}+0,33645 X_{5}+0,87516 X_{6}
\end{array}\right) \times 1,9324 \times t^{1,9324-1}}{\left[\begin{array}{l}
1+\exp \left(-8,7613+1,9324\left(0,00347 X_{1}-0,538 X_{2}-0,71326 X_{3}\right.\right. \\
\left.\left.+0,76395 X_{4}+0,33645 X_{5}+0,87516 X_{6}\right)\right) t^{1,9324}
\end{array}\right]}
$$

1. Uji Serentak (Rasio Likelihood) 
Berdasarkan hasil pada output software RStudio, diperoleh hasil perhitungan untuk nilai dari uji rasio likelihood sebagai berikut:

$$
\begin{aligned}
& G=-2[\ln L(0)-\ln L(\hat{\beta}) \\
& G=-2[-572,3-(-554,7)] \\
& G=35,2 \text { dengan p-value }=4,2 \mathrm{e}-06
\end{aligned}
$$

Pada taraf signifikansi $\alpha=5 \%, H_{0}$ ditolak karena nilai $G=35,2>\chi_{(5 \% ; 6)}^{2}=12,592$ dan nilai $p$-value $=4,2 e-06<\alpha=0,05$. Sehingga dapat disimpulkan bahwa terdapat minimal satu variabel bebas yang berpengaruh terhadap variabel terikat.

2. Uji Parsial

Berdasarkan hasil pada output software RStudio diperoleh nilai $Z$ dan $p$-value masing-masing variabel bebas pada Tabel 3:

Tabel 2. Hasil Regresi AFT Log-Logistik Model Awal

\begin{tabular}{lccc}
\hline \multicolumn{1}{c}{ Variabel } & \multicolumn{1}{c}{$\mathbf{Z}$} & $\boldsymbol{p}$-value & Keputusan \\
\hline Intercept & 20.89 & $<2 \mathrm{e}-16$ & $H_{0}$ ditolak \\
$X_{1}$ (Usia) & -0.65 & 0.5148 & $H_{0}$ diterima \\
$X_{2}$ (Laki-laki) & 2.51 & 0.0122 & $H_{0}$ ditolak \\
$X_{3}$ (Kateterisasi/Operasi) & 2.72 & 0.0066 & $H_{0}$ ditolak \\
$X_{4}(\geq 12 \mathrm{~mm})$ & -4.03 & $5.7 \mathrm{e}-05$ & $H_{0}$ ditolak \\
$X_{5}$ (Ada Hipertensi Pulmonal) & -1.85 & 0.0645 & $H_{0}$ ditolak \\
$X_{6}$ (Ya Nyeri) & -2.05 & 0.0406 & $H_{0}$ ditolak \\
\hline
\end{tabular}

Berdasarkan tabel 3 pada tingkat signifikansi $\alpha=5 \%, H_{0}$ ditolak untuk variabel jenis kelamin, treatment, ukuran defect, hipertensi pulmonal dan nyeri karena nilai $|Z|>Z_{0,025}=1,96$ dan $p$-value $<\alpha=0,05$. Sementara untuk variabel usia $H_{0}$ diterima karena nilai $|Z| \leq Z_{0,025}=1,96$ dan $p$-value $\geq \alpha=0,05$. Oleh karena itu dapat disimpulkan bahwa variabel jenis kelamin, treatment, ukuran defect, hipertensi pulmonal dan nyeri berpengaruh secara signifikan terhadap waktu survival pasien penderita ASD.

\subsubsection{Regresi AFT Log-Logistik Model Akhir}

Berdasarkan model awal, variabel bebas usia tidak signifikan terhadap waktu survival pasien penderita ASD, maka dari itu variabel usia dikeluarkan dari model dengan seleksi backward sehingga estimasi yang didapat dengan hanya variabel jenis kelamin, treatment, ukuran defect, hipertensi pulmonal dan nyeri seperti pada Tabel 7 berikut:

Tabel 3. Hasil Estimasi Koefisien Regresi AFT Log-Logistik Model Akhir

\section{Variabel}

\begin{tabular}{lc}
\hline Intercept $(\mu)$ & 4.4451 \\
$X_{2}$ (Laki-laki) & 0.5393 \\
$X_{3}$ (Kateterisasi/Operasi) & 0.7259 \\
$X_{4}(\geq 12 \mathrm{~mm})$ & -0.7640 \\
$X_{5}$ (Ada Hipertensi Pulmonal) & -0.3557 \\
$X_{6}$ (Ya Nyeri) & -0.8921
\end{tabular}




$$
\theta=\frac{-\mu}{\sigma}=-8,5813 \quad k=\frac{1}{\sigma}=1,93
$$

Berdasarkan pada Tabel 4 dengan rumus (18), (28) dan (29) maka diperoleh:

-Estimasi waktu survival model awal sebagai berikut:

$\hat{T}=\exp \left(4,4451+0,5393 X_{2}+0,7259 X_{3}-0,764 X_{4}-0,3557 X_{5}-0,8921 X_{6}\right)$

-Estimasi fungsi survival model sebagai berikut:

$$
\begin{aligned}
\hat{S}(t \mid X)= & {\left[1+\exp \left(-8,5813+1,93\left(-0,5393 X_{2}-0,7259 X_{3}\right.\right.\right.} \\
& \left.\left.\left.+0,764 X_{4}+0,3557 X_{5}+0,8921 X_{6}\right)\right) t^{1,93}\right]^{-1}
\end{aligned}
$$

-Estimasi fungsi kegagalan model sebagai berikut:

$$
\hat{h}(t \mid X)=\frac{\exp \left(\begin{array}{l}
-8,5813+1,93\left(-0,5393 X_{2}-0,7259 X_{3}\right. \\
\left.+0,764 X_{4}+0,3557 X_{5}+0,8921 X_{6}\right)
\end{array}\right) \times 1,93 \times t^{1,93-1}}{\left[\begin{array}{l}
1+\exp \left(-8,5813+1,93\left(-0,5393 X_{2}-0,7259 X_{3}\right.\right. \\
\left.\left.+0,764 X_{4}+0,3557 X_{5}+0,8921 X_{6}\right)\right) t^{1,93}
\end{array}\right]}
$$

1. Uji Serentak (Rasio Likelihood)

Berdasarkan persamaan hasil hasil pada output software RStudio, diperoleh hasil perhitungan untuk nilai dari uji rasio likelihood sebagai berikut:

$$
\begin{aligned}
& G=-2[\ln L(0)-\ln L(\hat{\beta}) \\
& G=-2[-572,3-(-555)] \\
& G=34,6 \text { dengan p-value }=1,8 \mathrm{e}-06
\end{aligned}
$$

Pada taraf signifikansi $\alpha=5 \%, H_{0}$ ditolak karena nilai $G=34,6 \chi_{(5 \% ; 6)}^{2}=11,070$ dan nilai $p$-value $=1,8 e-06<\alpha=0,05$. Sehingga dapat disimpulkan bahwa terdapat minimal satu variabel bebas yang berpengaruh terhadap variabel terikat.

2. Uji Parsial

Berdasarkan hasil pada output software RStudio diperoleh nilai $\mathrm{Z}$ dan $p$-value masing-masing variabel bebas pada Tabel 5:

Tabel 4. Hasil Regresi AFT Log-Logistik Model Akhir

\begin{tabular}{lclc}
\hline \multicolumn{1}{c}{ Variabel } & $\mathbf{Z}$ & $\boldsymbol{p}$-value & Keputusan \\
\hline Intercept & 25.74 & $<2 \mathrm{e}-16$ & $H_{0}$ ditolak \\
$X_{2}$ (Laki-laki) & 2.51 & 0.0121 & $H_{0}$ ditolak \\
$X_{3}$ (Kateterisasi/Operasi) & 2.75 & 0.0059 & $H_{0}$ ditolak \\
$X_{4}(\geq 12 \mathrm{~mm})$ & -1.97 & 0.0488 & $H_{0}$ ditolak \\
$X_{5}$ (Ada Hipertensi Pulmonal) & -4.02 & $5.7 \mathrm{e}-05$ & $H_{0}$ ditolak \\
$X_{6}$ (Ya Nyeri) & -2.09 & 0.0363 & $H_{0}$ ditolak
\end{tabular}

Berdasarkan tabel 5 pada tingkat signifikansi $\alpha=5 \%, H_{0}$ ditolak untuk variabel jenis kelamin, treatment, ukuran defect, hipertensi pulmonal dan nyeri karena nilai $|Z|>Z_{0,025}=1,96$ dan $p$-value $<\alpha=0,05$. Oleh karena itu dapat disimpulkan bahwa 
variabel jenis kelamin, treatment, ukuran defect, hipertensi pulmonal dan nyeri berpengaruh secara signifikan terhadap waktu survival pasien penderita ASD.

\subsubsection{Intepretasi Model Terbaik}

Intepretasi model digunakan untuk mengetahui acceleration factor dan fungsi survival jika diketahui variabel bebasnya. Berikut model yang telah terbentuk dari model terbaik yaitu:

-Estimasi waktu survival model awal sebagai berikut:

$\hat{T}=\exp \left(4,4451+0,5393 X_{2}+0,7259 X_{3}-0,764 X_{4}-0,3557 X_{5}-0,8921 X_{6}\right)$

-Estimasi fungsi survival model sebagai berikut:

$$
\begin{aligned}
\hat{S}(t \mid X)= & {\left[1+\exp \left(-8,5813+1,93\left(-0,5393 X_{2}-0,7259 X_{3}\right.\right.\right.} \\
& \left.\left.\left.+0,764 X_{4}+0,3557 X_{5}+0,8921 X_{6}\right)\right) t^{1,93}\right]^{-1}
\end{aligned}
$$

-Estimasi fungsi kegagalan model sebagai berikut:

$$
\hat{h}(t \mid X)=\frac{\exp \left(\begin{array}{l}
-8,5813+1,93\left(-0,5393 X_{2}-0,7259 X_{3}\right. \\
\left.+0,764 X_{4}+0,3557 X_{5}+0,8921 X_{6}\right)
\end{array}\right) \times 1,93 \times t^{1,93-1}}{\left[\begin{array}{l}
1+\exp \left(-8,5813+1,93\left(-0,5393 X_{2}-0,7259 X_{3}\right.\right. \\
\left.\left.+0,764 X_{4}+0,3557 X_{5}+0,8921 X_{6}\right)\right) t^{1,93}
\end{array}\right]}
$$

Diperoleh nilai acceleration factor untuk masing-masing variable bebas:

- Pasien ASD dengan jenis kelamin laki-laki memiliki nilai akselerasi 0,5832 kali dari pasien dengan jenis kelamin perempuan. Sehingga dapat disimpulkan bahwa pasien perempuan, secara rata-rata akan mengalami kekambuhan pertama lebih cepat.

- Pasien ASD yang telah menjalani treatment memiliki nilai akselerasi 0,4839 kali dari pasien yang belum menjalani treatment. Sehingga dapat disimpulkan bahwa pasien yang belum menjalani treatment, secara rata-rata akan mengalami kekambuhan pertama lebih cepat.

- Pasien ASD dengan ukuran defect $\geq 12 \mathrm{~mm}$ memiliki nilai akselerasi 2,1468 kali dari pasien dengan ukuran defect $<12 \mathrm{~mm}$. Sehingga dapat disimpulkan bahwa pasien dengan ukuran defect $\geq 12 \mathrm{~mm}$, secara rata-rata akan mengalami kekambuhan pertama lebih cepat.

- Pasien ASD dengan hipertensi pulmonal memiliki nilai akselerasi 1,4272 kali dari pasien tanpa hipertensi pulmonal. Sehingga dapat disimpulkan bahwa pasien dengan hipertensi pulmonal, secara rata-rata akan mengalami kekambuhan pertama lebih cepat.

- Pasien ASD dengan kondisi nyeri pada bagian dada memiliki nilai akselerasi 2,4402 kali dari pasien tanpa nyeri pada bagian dada. Sehingga dapat disimpulkan bahwa pasien dengan kondisi nyeri pada bagian dada, secara rata-rata akan mengalami kekambuhan pertama lebih cepat.

\section{KESIMPULAN}

Berdasarkan uraian pada bagian hasil dan pembahasan diperoleh kesimpulan sebagai bahwa faktor-faktor yang mampu mempengaruhi kekambuhan pertama pasien penderita ASD dengan menggunakan metode AFT Log-Logistik adalah variabel jenis kelamin, status treatment, ukuran defect, status hipertensi pulmonal, dan status nyeri, dengan penjabaran sebagai berikut:

- Pasien dengan jenis kelamin perempuan, secara rata-rata akan mengalami kekambuhan pertama lebih cepat dibandingkan pasien dengan jenis kelamin lakilaki. 
- Pasien yang belum menjalani treatment, secara rata-rata akan mengalami kekambuhan pertama lebih cepat dibandingkan pasien yang telah menjalani treatment.

- Pasien dengan ukuran defect $\geq 12 \mathrm{~mm}$, secara rata-rata akan mengalami kekambuhan pertama lebih cepat dibandingkan pasien dengan ukuran defect $<12 \mathrm{~mm}$.

- Pasien dengan hipertensi pulmonal, secara rata-rata akan mengalami kekambuhan pertama lebih cepat dibandingkan pasien yang tanpa hipertensi pulmonal.

- Pasien dengan kondisi nyeri pada bagian dada, secara rata-rata akan mengalami kekambuhan pertama lebih cepat dibandingkan pasien tanpa nyeri pada bagian dada.

\section{DAFTAR PUSTAKA}

Athoillah, I., Wuryandari, T. \& Sudarno, 2012. Model Regresi Data Tahan Hidup Tersensor Tipe III Berdistribusi Log-Logistik. Jurnal Gaussian Vol. I, No.1: hal 84-92.

Collet, D., 2004. Modelling Survival Data in Medical Research. 2nd ed. London: Chapman and Hall.

Danardono, 2012. Analisis Data Survival. Yogyakarta: Universitas Gadjah Mada.

Harlan, J., 2017. Analisis Survival. Depok: Gunadarma.

Hosmer, D. W., Lemeshow, S. \& May, S., 2008. Applied Survival Analysis: Regression Modelling of Time-to-Event Data. 2nd ed. New Jersey: John Wiley and Sons, Inc..

John , P. K. \& Melvin , L. M., 2003. Survival Analysis: Techniques for Censored and Turncated Data. 2nd ed. New York: Springer-Verlag New York.

Kleinbaum, D. G. \& Klein, M., 2005. Survival Analysis: A Self-Leranin Text. 2nd ed. New York: Springer.

Kusumawardhani, G. E., Suyono \& Santi, V. M., 2018. Analisis Suvival dengan Model Regresi pada Data Tersensor Berdistribusi Log-Logistik. Jurnal Statistika dan Aplikasinya (JSA) Vol. II, No. 2: hal 28-35.

Lawless, J. F., 2003. Statistical Models and Methods for Lifetime Data. 2nd ed. Canada: John Wiley and Sons, Inc.

Lee, E. T. \& Wang, J. W., 2003. Statistical Methods for Survival Data Analysis. 3rd ed. New Jersey: John Wiley \& Sons, Inc.

Mufidah, A. S. \& Purhadi, 2016. Analisis Survival pada Pasien Deman Berdarah Dengue (DBD) di RSU Haji Surabaya. Jurnal Sains dan Seni Vol V, No. 2.

Naysilla, A. M., 2017. Komplikasi pada Pasien Atrial Septal Defect Dewasa dengan Survivalitas Alami. Indonesia Jurnal Chest Vol. IV, No. 4: hal 23-34.

Wardhana, W. \& Boom, C. E., 2017. Penanganan Perioperatif Pasien Penyakit Jantung Kongenital Dewasa dengan ASD, Suspek Hipertensi Pulmonal, LV Smallish. Jurnal Anastesiologi Indonesia Vol. IX, No. 2: hal 71-86. 